\title{
Gymnodinium Brown Tide in the Magellanic Fjords, Southern Chile
}

\author{
Marea café provocada por Gymnodinium en los fiordos magallánicos (Sur de Chile)
}

\section{Juan Carlos Uribe \& Milena Ruiz}

\author{
Instituto de la Patagonia, Universidad de Magallanes \\ P.O. Box 113-D, Punta Arenas, Chile. \\ jcuribe@aoniken.fc.umag.cl
}

\begin{abstract}
In April 1999, a brown tide was recorded in the Magellanic fjords, Southern Chile. The causative taxa were two unidentified morphs of Gymnodinium that resemble Gymnodinium mikimotoi Miyake et Kominami ex Oda. Although there were many reports from fishermen about water discolorations along the region, just two localities were sampled by scientific personnel: the oceanic entrance of Canal

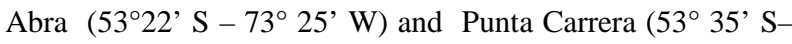
$70^{\circ} 55^{\prime} \mathrm{W}$ ), which is situated in the Strait of Magellan. After discolorations, Gymnodinium concentrations ranged between 3,000 to 43,000 cells L- 1 . The Gymnodinium bloom lasted for about three weeks in the fjords. Invertebrates (sea urchins, sea stars, snails, limpets, octopus) and fish were reported as dead, but no quantification was done.

This phenomenon took place some weeks after a bloom of Gymnodinium, recorded around Chiloé Island ( $42^{\circ} 30 \mathrm{~S}-73^{\circ}$

$\left.55^{\prime} \mathrm{W}\right)$. Neither species form part of the normal flora in the Southern chilean fjords and their blooming supports the idea of a large scale phytoplankton transport along South East Pacific coast.
\end{abstract}

Keywords: Red Tides, HAB, marine mortalities
Resumen.- En abril de 1999 se registró una marea café en la región de fiordos y canales magallánicos. Los taxa causantes fueron dos morfos no identificados de Gymnodinium, los que guardan un parecido con Gymnodinium mikimotoi Miyake et Kominami ex Oda. Aunque hubo numerosos informes de pescadores acerca de discoloraciones a lo largo de la región, sólo dos localidades fueron investigadas por personal científico: la entrada oceánica de

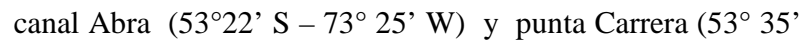
S- $70^{\circ} 55^{\prime} \mathrm{W}$ ), que se encuentra en el estrecho de Magallanes. Las concentraciones de Gymnodinium, evaluadas después de las discoloraciones, variaron entre 3.000 a 43.000 cél. $\mathrm{L}^{-1}$. La floración de Gymnodinium duró aproximadamente tres semanas en los fiordos. Se verificó la muerte de invertebrados (erizos de mar, estrellas de mar, mauchos, caracoles y pulpos) y peces, pero no se efectuaron cuantificaciones.

Este fenómeno tuvo lugar algunas semanas después de una floración de Gymnodinium alrededor de la isla de Chiloé (42 $30 \mathrm{~S}-73^{\circ} 55^{\prime} \mathrm{W}$ ). Este taxa no forma parte de la flora común de los fiordos del sur de Chile y su floración en subsistemas muy separados entre sí y solo conectados a través del océano presta apoyo a la idea de un transporte de fitoplancton a gran escala a lo largo de la costa del Pacífico Sureste.

Palabras claves: marea roja, FAN, mortandades marinas

\section{Introduction}

Southern Chile is characterized by a broken coast line with hundreds of channels and fjords, extending over nearly $1,500 \mathrm{~km}$ from around 41.5 to $56^{\circ} \mathrm{S}$. This archipelagic fjord region is the only one place in South East Pacific where extensive Harmful Algal Blooms (HAB) have been recorded. Several prolonged and intensive Paralytic Shellfish Poisoning (PSP) outbreaks caused by Alexandrium catenella (Whedon et Kofoid) Balech have happened since 1972 (Guzmán et al. 1975, Lembeye 1981). Dinoflagellate blooms associated with Diarrhetic Shellfish Poison (DSP), of shorter duration but extending along this region have also been recorded
(Lembeye et al. 1993, Uribe et al. 2001). Moreover, noxious blooms affecting salmon farming activity have also taken place in the northern part of this zone (Clément \& Lembeye 1993).

On 8 April 1999, a group of fishermen reported, to the Fisheries Authority in Punta Arenas, seawater discolorations that ocurred in many localities along Magellanic fjords (those located in XII region or Magellan Region). The phenomenon was associated with mortality of invertebrates and fish. One of the areas mentioned was Canal Abra (5322' S - 73 25' W) where hundreds of sea urchins, sea stars, octopuses and congers were washed ashore. On the next day, the 
Coast Guard from Punta Arenas made a flight by helicopter to the site, to collect water samples, which were analysed by the Instituto de Fomento Pesquero (IFOP) (Guzmán et al. 1999). Later, on Monday 12 April, the Coast Guard provided a cutter cruise to the site with IFOP personnel on board, who collected samples in a more systematic way. Parts of those samples were kindly passed to the Instituto de la Patagonia, Universidad de Magallanes.

In the following week fishermen reported water discolorations in the northern area of the Magellan Region, including Grupo Lobos (51 $31^{\circ} \mathrm{S}-74^{\circ} 45^{\prime} \mathrm{W}$ ) and Canal Oeste $\left(50^{\circ} 30^{\prime} \mathrm{S}-75^{\circ} 15^{\prime} \mathrm{W}\right)$. A flight over this and other sectors was carried out on 16 April by a Navy plane. Samples were also collected on 17 April in Punta Carrera, $50 \mathrm{~km}$ south of Punta Arenas, to determine the presence of the causative microorganism in the inner part of the fjord system. Here we summarize the findings made during this brown tide in the Magellanic waters.

\section{Material and Methods}

Qualitative phytoplankton samples from Canal Abra (Fig. 1) were collected by vertical tows of a $20 \mu \mathrm{m}$ net and fixed in Lugol's iodine. Two additional hydrographic stations (named inner and outer) were sampled at Punta Carrera, Strait of Magellan (Fig. 1). Net phytoplankton samples from this area were fixed in glutaraldehide 2.5\%. Quantitative samples of phytoplankton were taken only in Punta Carrera, by using a $10 \mathrm{~m}$ hose that permitted an integrated sample of the water column. In this case, the material was fixed with a $1 \%$ formalin solution. Qualitative analyses were made with a standard optical microscope, whereas quantitative analyses were done with an inverted microscope (Hasle 1978). In Punta Carrera temperature and salinity profiles were also recorded with a SBE-19 CTD.
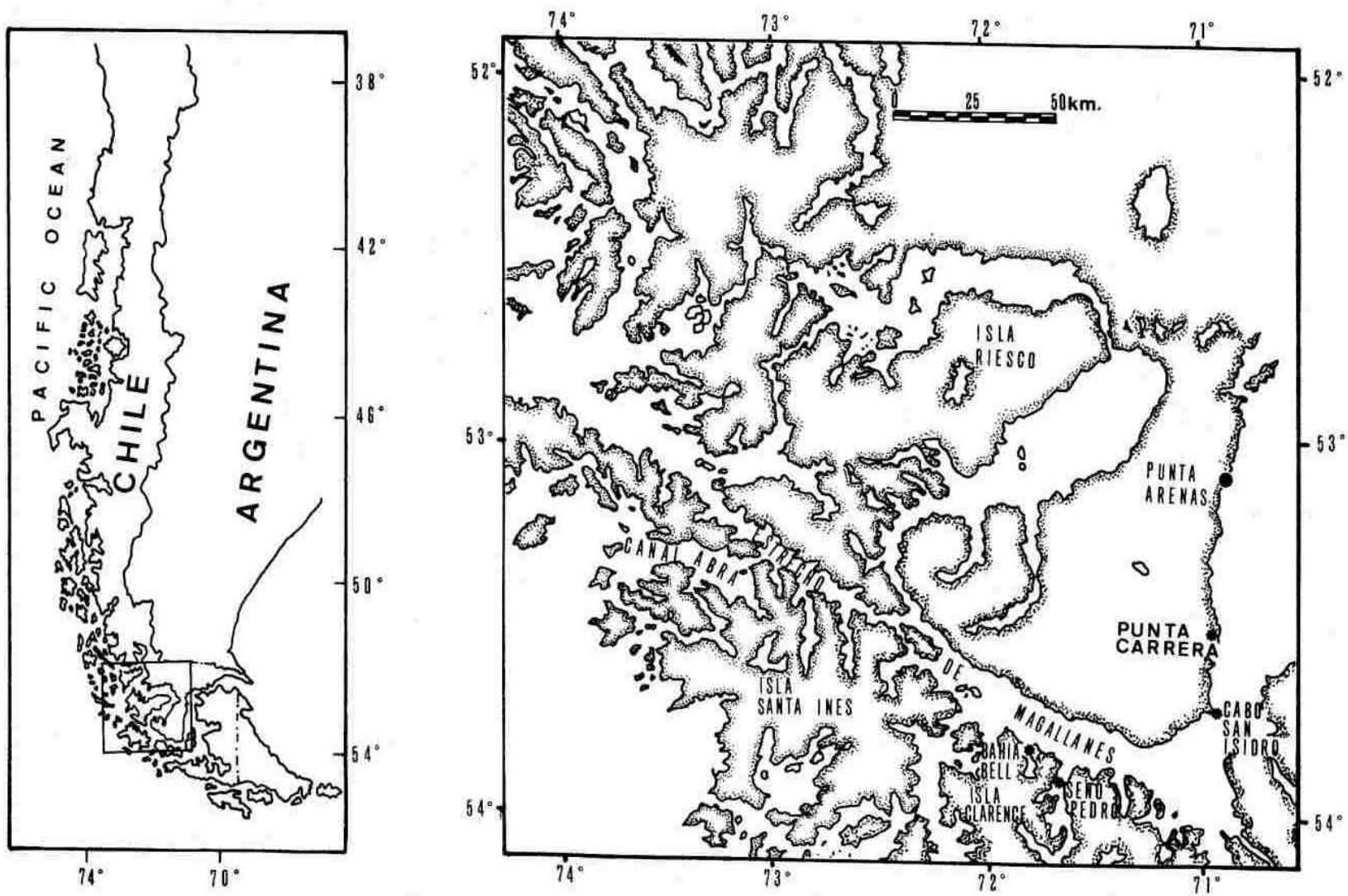

Figure 1

Location of the sampling sites

Ubicación de los sitios de muestreo 
Part of the net samples were sent to the Electronic Microscopy Laboratory (University of Concepción) where they were treated by conventional methods, applied to delicate specimens (Cohen 1974). The material was observed in a scanning microscope ETEC, Autoscan U-1.

\section{Results}

The flight to Canal Abra permitted to observe the water discoloration reported by fishermen, that was especially evident in the oceanic entrance of this channel (R. Schipmann pers. com.). During the later flight that lasted over two hours over the northern area of Magellanic region no evidence of a brown tide was observed.

Net samples collected in Canal Abra showed the existence of a rich phytoplankton assemblage, including 18 species of diatoms and 15 species of dinoflagellates. Species of the genus Ceratium, Dinophysis and Gymnodinium were well represented (Table 1). The qualitative composition of the samples taken in Punta Carrera on 17 April was very similar (Table 2). In both localities, the presence of two Gymnodinium morphs were observed (indicated as Gymnodinium sp. 1 and Gymnodinium sp. 2 in the tables).

Before the appearance of this phenomenon, two sampling sites had been periodically visited in Punta Carrera giving an opportunity to follow phytoplankton structure changes during the brown tide. Quantitative composition at the end of March was characterized by scarce phytoplankton concentration (Table 2). However, it is interesting to note that cells of Gymnodinium were present at that time. This was verified by a second analysis, when the brown tide was known. On 17 April, the phytoplankton concentration increased notably due to the presence of dinoflagellates, specially of the genus Gymnodinium. Both morph rose to 32,600 cells $\mathrm{L}^{-1}$ in the inner station and 32,400 cells $\mathrm{L}^{-1}$ in the outer one, making up more than $90 \%$ of the entire sample (Table 2). This result stimulated to carry out one second visit to this site, a week later, but as it is shown in Table 2, the Gymnodinium concentration and all the other species were by then much lower.

Morphometric evaluations were made on fixed cells of both morphs. Gymnodinium sp. 2 was smaller, but partly overlapping in size with Gymnodinium sp.1 (Table 3). Both morphs had a premedian cingulum with a displacement less than a 1/5 of body length (Figs 2, 4). A sulcal extension was evident in both morphs (Figs 2, 4). A swelling caused by fixation was observed, since live cells (at least in Gymnodinium sp. 1) were flattened dorso-ventrally, whereas fixed cells were more spherical. In spite of this, it was possible to observe a clear difference in the outline of the cells of the two morphs as is showed in Table 3 and Figs 2-7. Other differences included a prominent apical groove present in Gymnodinium sp. 1 (Fig. 2) as compared with the very inconspicuos one in Gymnodinium sp. 2 (Fig. 4). The apical groove of Gymnodinium sp. 1 occupied ca. $2 / 3$ of the ventral zone of the episome, from the contact point to the sulcal extension, intruding for a short distance in the dorsal zone (Figs 2, 3). Moreover, in the ventral zone, the apical groove was surrounded by a prominent ridge along the right side (Fig. 2). The nucleus of Gymnodinium sp. 1 was prominent, quite spherical and bigger than that of Gymnodinium sp. 2 (Figs 6-7). In both forms the nuclei were located in a subcentral position in the hyposome (Figs. 6, 7). Chloroplasts were ellipsoid in both morphs (not shown), but the number per cell was lower in Gymnodinium sp. 2 (Table 3).

From the reports of the fishermen and the observations made by the Coast Guard and by the authors, it was possible to establish a toxic effect of the blooms upon the marine fauna, since a profusion of dead organisms were washed ashore in the areas visited.

On 25 April, dwellers from Punta Carrera, a rural locality, reported mortality of many invertebrates in that area, and it was possible to verify the presence of sea urchins (Loxechinus albus Molina), limpets (Fisurella spp.) and a lesser proportion of Magellanic limpets (Nacella magellanica Gmelin) in the rocky shore, being partly consumed by seagulls. A similar situation was observed by a team of benthologists of the Instituto de la Patagonia in a nearby locality during the previous days. On the same day (25 April) the death of 700 scallops (Chlamys patagonica), mantained experimentally in Punta Carrera since December 1998 was verified. This differs from the $100 \%$ of scallop survival observed since the beginning of that experiment. 
Table 1

Phytoplankton composition in Punta Carrera and Canal Abra

Composición del fitoplancton en Punta Carrera y Canal Abra

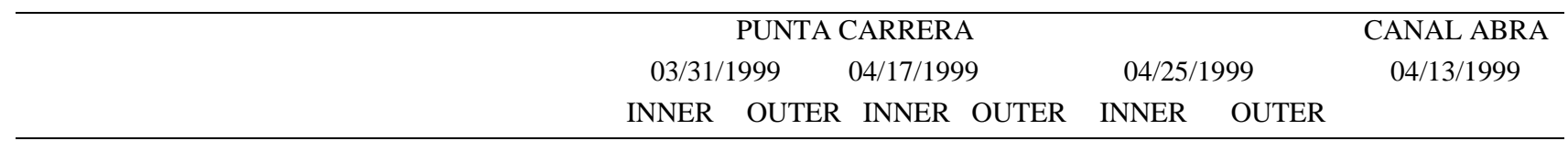

DIATOMS

Asterionellopsis glacialis (Castracane) Round Asterionella sp.

Biddulphia sp.

Cerataulina pelagica (Cleve) Hendey

Corethron criophilum Castracane

Coscinodiscus sp. A

Cylindrotheca closterium (Ehrenberg) Lewin \&

Reimann

Chaetoceros compressus Lauder

Chaetoceros constrictus Gran

Chaetoceros curvisetus Cleve

Chaetoceros convolutus Castracane

Chaetoceros decipiens Cleve

Chaetoceros diadema (Ehrenberg) Gran

Chaetoceros didymus Ehrenberg

Chaetoceros tortissimus Gran

Dytilum brightwelli ( West) Grunow

Fragilaria virescens Ralfs

Guinardia delicatula (Cleve) Hasle

Leptocylindrus danicus Cleve

Leptocylindrus minimus Gran

Navicula sp.

Nitzschia longissima (Brébisson) Ralfs

Nitzschia sp.

Pennates undet.

Pleurosigma normanii Ralf

Pleurosigma sp.

Proboscia alata (Brightwell) Sundström

Pseudo-nitzschia cf. pseudodelicatissima

Pseudo-nitzschia cf. australis

Rhizosolenia hebetata Bailey

Rhizosolenia setigera Brightwell

Skeletonema costatum (Greville) Cleve

Stephanopyxis palmeriana (Greville) Grunow

Striatella unipunctata (Lyngbye) C. A. Agardh

Thalassiosira cf. gerloffii

Thalassiosira cf. mendiolana

Thalassiosira cf. anguste-lineata

Tropidoneis sp.

DINOFLAGELLATES

Alexandrium catenella (Whedon \& Kofoid)

Balech

Ceratium fusus (Ehrenberg) Dujardin

Ceratium lineatum (Ehrenberg) Cleve

Ceratium minutum Jorgensen

Ceratium pentagonum Gourret

Ceratium tripos (O.F.Müller) Nitzsch

Ceratium sp.

Dinophysis acuminata Claparède \& Lachmann

Dinophysis acuta Ehrenberg

Dinophysis truncata Cleve

Dinophysis sp.

Dyplopsalis sp

Gonyaulax sp.

Gymnodinium sp. 1

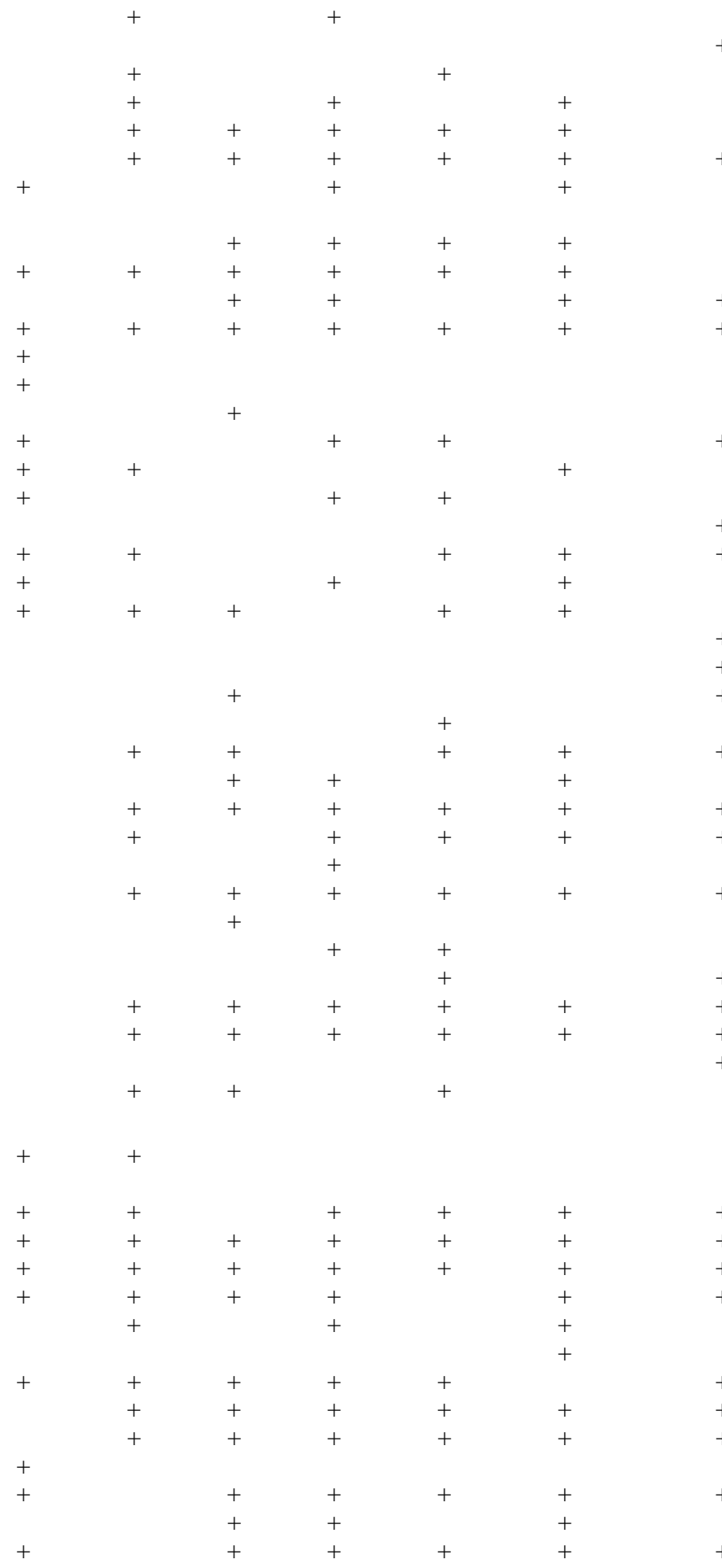




\begin{tabular}{|c|c|c|c|c|c|c|c|}
\hline & \multicolumn{4}{|c|}{ PUNTA CARRERA } & & & \multirow{3}{*}{$\begin{array}{c}\text { CANAL } \\
\text { ABRA } \\
04 / 13 / 1999\end{array}$} \\
\hline & \multicolumn{2}{|c|}{ 03/31/1999 } & \multicolumn{2}{|c|}{ 04/17/1999 } & \multicolumn{2}{|c|}{ 04/25/1999 } & \\
\hline & INNER & OUTER & INNER & OUTER & INNER & OUTER & \\
\hline Gymnodinium sp. 2 & & & + & & + & + & + \\
\hline Gyrodinium sp. & & & & & & & + \\
\hline Phalacroma rotundatum (Claparède $\&$ & & & & & + & & \\
\hline Lachmann) Kofoid \& Michener & & & & & & & \\
\hline Protoperidinium cf. oceanicum & & + & + & & & & \\
\hline Protoperidinium cf. pallidum & + & & + & + & & + & + \\
\hline Protoperidinium cf. pentagonum & & & & + & & & \\
\hline Protoperidinium claudicans (Paulsen) Balech & & & & + & & + & \\
\hline Protoperidinium conicum (Gran) Balech & + & + & + & + & & + & \\
\hline Protoperidinium crassipes (Kofoid) Balech & & & & + & & & \\
\hline Protoperidinium divergens (Ehrenberg) & & & & + & & & \\
\hline Balech & & & & & & & \\
\hline Protoperidinium pellucidum Bergh & + & + & + & + & + & + & \\
\hline Protoperidinium sp. & & & + & + & + & & + \\
\hline Scrippsiella trochoidea ( Stein) Loeblich III & & + & & + & + & + & \\
\hline SILICOFLAGELLATES & & & & & & & \\
\hline Dictyocha speculum Ehrenberg & + & + & + & + & + & + & + \\
\hline EUGLENOPHYTES & & & & & & & \\
\hline Euglenoides indet. & & & & & + & & \\
\hline NUMBER OF TAXA & 24 & 33 & 34 & 41 & 36 & 37 & 33 \\
\hline
\end{tabular}

Table 2

Phytoplankton concentration (cells $\mathrm{L}^{-1}$ ) in Punta Carrera Concentración del fitoplancton (céls. $\mathrm{L}^{-1}$ ) en Punta Carrera

\begin{tabular}{|c|c|c|c|c|c|c|}
\hline & \multirow{2}{*}{\multicolumn{2}{|c|}{ 03/31/1999 }} & \multirow{2}{*}{\multicolumn{2}{|c|}{$\begin{array}{l}\text { 04/17/1999 } \\
\text { STATIONS }\end{array}$}} & \multirow{2}{*}{\multicolumn{2}{|c|}{$04 / 25 / 1999$}} \\
\hline & & & & & & \\
\hline & Inner & Outer & Inner & Outer & Inner & Outer \\
\hline \multicolumn{7}{|l|}{ DIATOMS } \\
\hline $\begin{array}{l}\text { Cylindrotheca closterium (Ehrenberg) Lewin } \\
\text { \& Reimann }\end{array}$ & 100 & 0 & 0 & 0 & 100 & 0 \\
\hline Chaetoceros convolutus Castracane & 0 & 0 & 0 & 0 & 0 & 1300 \\
\hline Dytilum brightwelli (West) Grunow & 0 & 200 & 200 & 0 & 0 & 0 \\
\hline Fragillaria virescens Ralfs & 1100 & 0 & 0 & 1300 & 400 & 0 \\
\hline Leptocylindrus minimus Gran & 0 & 800 & 0 & 0 & 0 & 0 \\
\hline Navicula sp. & 0 & 200 & 100 & 0 & 0 & 200 \\
\hline Pennates undet. & 0 & 0 & 100 & 0 & 0 & 0 \\
\hline Pleurosigma sp. & 0 & 0 & 0 & 0 & 0 & 100 \\
\hline Pseudonitzschia cf. pseudodelicatissima & 0 & 0 & 0 & 300 & 100 & 300 \\
\hline Pseudonitzschia cf. australis & 0 & 0 & 0 & 100 & 0 & 0 \\
\hline Rhizosolenia setigera Brightwell & 0 & 100 & 0 & 200 & 0 & 0 \\
\hline Skeletonema costatum (Greville) Cleve & 0 & 0 & 0 & 300 & 0 & 0 \\
\hline Thalassiosira cf. gerloffii & 0 & 0 & 200 & 0 & 0 & 0 \\
\hline Tropidonies sp. & 100 & 0 & 0 & 0 & 0 & 0 \\
\hline \multicolumn{7}{|l|}{ DINOFLAGELLATES } \\
\hline Ceratium lineatum (Ehrenberg) Cleve & 0 & 0 & 600 & 200 & 0 & 0 \\
\hline
\end{tabular}




\begin{tabular}{|c|c|c|c|c|c|c|}
\hline & \multirow{2}{*}{\multicolumn{2}{|c|}{$03 / 31 / 1999$}} & \multirow{2}{*}{\multicolumn{2}{|c|}{$\begin{array}{c}\text { 04/17/1999 } \\
\text { STATIONS }\end{array}$}} & \multirow{2}{*}{\multicolumn{2}{|c|}{$04 / 25 / 1999$}} \\
\hline & & & & & & \\
\hline & Inner & Outer & Inner & Outer & Inner & Outer \\
\hline Ceratium minutum Jorgensen & 0 & 0 & 0 & 500 & 100 & 0 \\
\hline Ceratium pentagonum Gourret & 400 & 100 & 0 & 0 & 0 & 0 \\
\hline Dinophysis acuminata Claparède \& & 100 & 0 & 100 & 0 & 100 & 0 \\
\hline \multicolumn{7}{|l|}{ Lachmann } \\
\hline Dinophysis acuta Ehrenberg & 0 & 0 & 100 & 0 & 0 & 0 \\
\hline Diplopsalis sp. & 100 & 0 & 600 & 0 & 100 & 0 \\
\hline Gymnodinium sp. 2 & 0 & 0 & 15600 & 17200 & 0 & 500 \\
\hline Gymnodinium sp. 1 & 1900 & 0 & 17100 & 16300 & 400 & 900 \\
\hline Gyrodinium sp. & 0 & 0 & 0 & 0 & 0 & 100 \\
\hline Protoperidinium pellucidum Bergh & 0 & 0 & 300 & 100 & 0 & 0 \\
\hline Protoperidinium sp. & 0 & 0 & 0 & 0 & 100 & 0 \\
\hline Scrippsiella trochoidea (Stein) Loeblich III & 0 & 0 & 0 & 0 & 300 & 0 \\
\hline \multicolumn{7}{|l|}{ OTHERS } \\
\hline Dictyocha speculum Ehrenberg & 200 & 0 & 200 & 0 & 100 & 0 \\
\hline Euglenoides undet. & 0 & 0 & 0 & 0 & 0 & 100 \\
\hline DIATOMS & 1300 & 1300 & 600 & 2200 & 600 & 1900 \\
\hline DINOFLAGELLATES & 2500 & 100 & 34400 & 34300 & 1100 & 1500 \\
\hline TOTAL ABUNDANCE & 4000 & 1400 & 35200 & 36500 & 1800 & 3500 \\
\hline
\end{tabular}

Table 3

Comparison of some features of the two morphs found in Magellan waters with G. mikimotoi* Comparación de algunos rasgos de los dos morfos encontrados en Magallanes con G. mikimotoi*

\begin{tabular}{|c|c|c|c|c|c|c|c|}
\hline & & & & Species & & & \\
\hline & & Gymnodir & um sp. 1 & Gymnodi & $n$ sp. 2 & Gymnodin & im mikimotoi \\
\hline Featur & & Mean & Range & Mean & Range & Mean & Range \\
\hline Size & Body lenght & $44.7 \mu \mathrm{m}$ & $38-48 \mu \mathrm{m}$ & $41.4 \mu \mathrm{m}$ & $32-48 \mu \mathrm{m}$ & $28.3 \mu \mathrm{m}$ & $21-34 \mu \mathrm{m}$ \\
\hline & Body width & $45.1 \mu \mathrm{m}$ & $32-54 \mu \mathrm{m}$ & $37.4 \mu \mathrm{m}$ & $32-42 \mu \mathrm{m}$ & $23.5 \mu \mathrm{m}$ & $16-29 \mu \mathrm{m}$ \\
\hline Body & Shape & & & & & & \\
\hline & Episome & Broadly c & nical & Rounded & & Rounded & \\
\hline & Hyposome & Truncated & rone & Rounded & ched & sligthly b & obed \\
\hline Apical & roove & Marked & & Inconspi & & Marked & \\
\hline Chloro & asts (shape) & Ellipsoid & & Ellipsoid & & $\begin{array}{l}\text { Rounded, } \\
\text { sometimes }\end{array}$ & ymmetric \\
\hline Chloro & asts per cell & $56+/-9$ & & $34+/-8$ & & $18+/-6$ & \\
\hline Chloro & ast lenght & $9.6 \mu \mathrm{m}$ & & $9.6 \mu \mathrm{m}$ & & 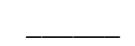 & \\
\hline
\end{tabular}

( * As G. nagasakiense in Partensky et al., 1988) 

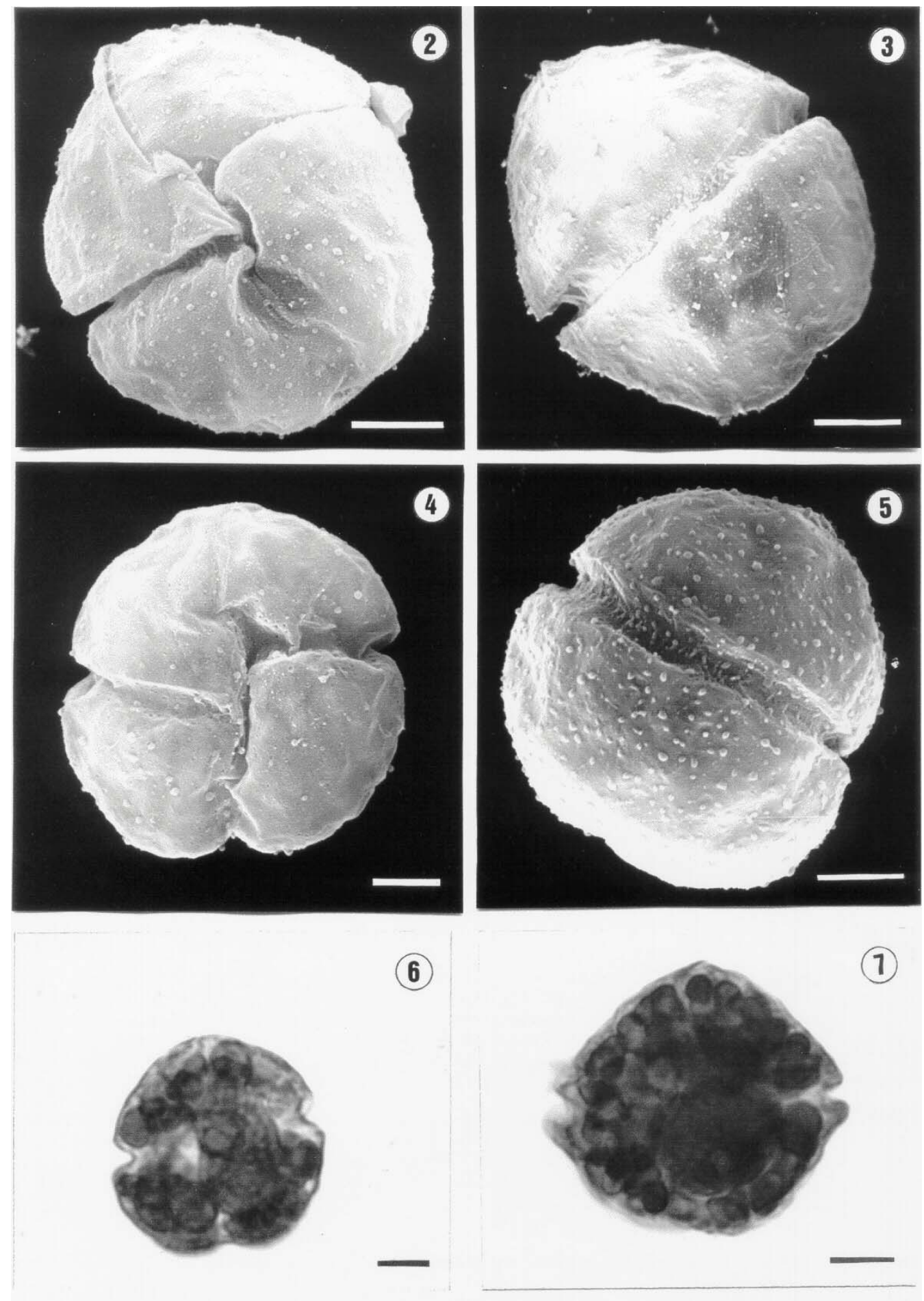

Figure 2-7

Gymnodinium sp. 1 (Figs. 2,3,7) and Gymnodinium sp. 2 (Figs. 4-6). Fig. 2. Ventral view of Gymnodinium sp. 1. Fig. 3. Dorsal view of Gymnodinium sp. 1. Fig. 4. ventral view of Gymnodinium sp. 2. Fig. 5. Dorsal view of Gymnodinium sp 2. Fig. 6. Gymnodinium sp. 2 outline (optical microscopy). Fig. 7. Gymnodinium sp. 1 outline (optical microscopy). Each bar represent $10 \mu \mathrm{m}$.

Gymnodinium sp. 1 (Figs. 2,3,7) y Gymnodinium sp. 2 (Figs. 4-6). Fig. 2. Vista ventral de Gymnodinium sp. 1. Fig. 3. Vista dorsal de Gymnodinium sp. 1. Fig. 4. Vista ventral de Gymnodinium sp. 2. Fig. 5. Vista dorsal de Gymnodinium sp 2. Fig. $6 . \quad$ Contorno de Gymnodinium sp. 2 outline (microscopía óptica). Fig. 7. Contorno de Gymnodinium sp. 1 (microscopía óptica). Cada barra representa 10 $\mu \mathrm{m}$. 


\section{Discussion}

The above description represent the first record of a brown tide in Magellanic waters. Some weeks before, a similar phenomenon took place at Chiloé Island $\left(42^{\circ} 30\right.$ $\mathrm{S}-73^{\circ} 55^{\prime} \mathrm{W}$ ), produced also by a Gymnodinium sp. (Clément 1999), probably the same species as described here.

The term brown tide is too much broad for characterizing a phytoplanktonic bloom, since brown water discolorations can be produced by microorganisms as different as Aureococcus anophagefferens Hargraves et Sieburth (Cosper et al., 1989), Aureoumbra lagunensis De Yoe \& Stockwell (Villareal et al. 1997) or Gymnodinium mikimotoi Miyake et Kominami ex Oda (Hansen et al. 2000), all of them with singular peculiarities. For these reasons comparison must be restricted to species or genus levels.

Brown tides produced by Gymnodinium are known in Europe, Australia, Japan and Korea (Taylor et al. 1995). Gymnodinium cf. nagasakiense has been described as a common blooming species from Norway $\left(70^{\circ} \mathrm{N}\right)$ (Braarud \& Heimdal 1970) to the coast of Spain $\left(40^{\circ} \mathrm{N}\right)$ (Fraga \& Sánchez 1985) and specially in the coast of Brittany (Partensky et al. 1991).

The features evaluated in these Gymnodinium did not permit the assignment to any particular species, since this genus is highly complex and comprises more than 200 species with high morphological variability (Taylor et al. 1995). Moreover, as indicated by Haywood et al. (1996) morphological changes occur in preserved material reducing the possibility of accurate identification. However, we consider both morphs as distinct and not the result of different stress, since they were obtained from the same samples. Both share features with G. mikimotoi and with others species like Gymnodinium sp. (Mackenzie et al. 1996). The presence of a groove was characteristic in Gymnodinium sp.1 resembling that of G. mikimotoi, but it is clearly more prominent than those reported by Partensky et al. (1988) and Hansen et al. (2000). The cell outline of Gymnodinium sp.1 differed from G. mikimotoi especially by the length/wide ratio as indicated in Hansen et al. (2000). Gymnodinium sp. 2 presented a more similar outline to G. mikimotoi, ${ }_{2}$ but differed notably in the apical groove. Both morphs were larger than G. mikimotoi, altough they overlap in the upper range of the larger G. mikimotoi isolate, mentioned in Hansen et al. (2000). In Gymnodinium sp. 1 and Gymnodinium sp. 2 the position of the nucleus was also different from the above mentioned species of Gymnodinium, since it was more spherical and centrally located. Both morphs could represent new species in this highly complex genus, but the alternative of different stages of the same species can not be discarded. Pigment composition analisis made by Carreto et al. (2001), on Gymnodinium sp. from Chiloé bloom did not throw light on this subject either.

Gymnodinium of nagasakiense (= G. mikimotoi) is one of the best studied species in the genus, and it is described as eurytherm and euryhaline (Nielsen \& Tonseth 1991). However, high concentrations of this species has been associated with high temperatures and high salinities (Roden et al. 1981, Partensky \& Sournia 1986). Occasionally this species has been observed in waters with low temperatures $\left(<10^{\circ} \mathrm{C}\right)$ (Tangen, 1977) and low salinities (Braarud \& Heimdal 1970). The mean temperature and salinity at Punta Carrera, recorded during the sampling period, were $8.40{ }^{\circ} \mathrm{C}$ and $30.06 \mathrm{psu}$ respectively, and both are normal values during the autumn. In Chiloé, higher concentrations of Gymnodinium were associated with temperatures above $13.5^{\circ} \mathrm{C}$ and salinities above 33.2 psu (Clément op. cit.).

Another known characteristic of the ecology of these species is that when blooms arise, they are often associated with an off shore tidal front, spreading later to the coastal zone (Arzul 1993). This situation seems to be coincident with the observations in the Patagonic fjords. It was evident both in Chiloé and in the Magellan Region, that brown patches were well developed in the oceanic entrance of the fjord system and later the microorganisms were detected in the inner waters. These observations and the other common features such as the quasi-simultaneous blooming and the presence of the same genus as a major component, indicate that both episodes could represent a manifestation of one major event. However, the lack of sampling in the geographic space in between, and the different methods used to fix the material, preclude a definitive conclusion. At Chiloé, various sites were evaluated and a maximum of 4,000,000 cells $\mathrm{L}^{-1}$ was detected (Clément 1999). In the Magellan Region, the brown patches observed in Canal Abra indicated high concentrations of the microorganism but the survey made by IFOP showed a maximum of 43,000 cells $\mathrm{L}^{-1}$ (Guzmán et al. 1999). Two days before this sampling, a windy front reached the Magellan Region and seemed to be the most probably factor that dissipated the brown tide. The lower values detected at Punta Carrera indicate a limited dispersion into the inner waters. However, it must be considered that higher concentrations could be reached since the high motility of dinoflagellates permit them to concentrate at specific depths (Passow 1991).

At Chiloé the phenomenon lasted around one month, from the second week of March to the second week of April (Clément op. cit.). In Magellan waters the phenomenon stayed for a shorter time. In samples 
obtained between 24 March and 27 March, Gymnodinium was not detected by a Red Tide Monitoring Program in localities nearby Punta Carrera: Bahía Bell, Seno Pedro, San Isidro (see Fig 1) (Guzmán et al. 1999). Moreover, the data obtained on 25 April, indicates a very low concentration. Thus, it can be assumed that the concentration of Gymnodinium declined quickly and its blooming last roughly three weeks.

Gymnodinium cf. nagasakiense, and G. mikimotoi, two very close taxa are commonly cited as causing invertebrate mortalities world-wide, including cultivated species of mussels, scallops and also salmonids (Parstensky et al. 1988, Mahoney et al. 1990). The death of wild fishes trapped in coastal zones by the blooming of this species has also been reported (Arzul, 1993). Concentracions of G. cf. nagasakiense, able to produce toxic effects in marine fauna are variable. Widdows et al. (1979), reported that $100,000{\text { cells } l^{-1}}^{-1}$ can cause damage in the gut cells of experimentally exposed mussels. In Chiloé, the brown tide caused the death of more than 750,000 farmed salmonids, equivalent to 1,155 tons, in various centers of that archipelago (Clément op. cit.). Others species, such as abalone and native fauna were also affected. In both cases, death was attributed to toxic effects instead of oxygen deprivation (Clément op. cit.). This Gymnodinium showed a strong haemolytic and allelopathic activity (Clément et al. 2001). In Magellan waters the association between Gymnodinium and invertebrate mortalities was evident. Its lethal effects was observed also in Canal Fallos $\left(48^{\circ} 37 \mathrm{~S}-75^{\circ} 00 \mathrm{~W}\right)$ where a big bed of mussels (Aulacomya ater Molina), sampled over many years, was decimated (Guzmán et al. 1999). The low concentration of Gymnodinium detected in Magellanic waters as compared to others reports (Mahoney et al. 1990) permit us to presume it was a bloom of highly toxic cells.

This sudden Gymnodinium blooming in many unconnected fjord subsystems, support the idea of a large scale phytoplankton transport along this part of the South Eastern Pacific, that until now remain as a quite unknown system. A similar situation seems to happen with A. catenella blooms (Uribe 1992). Therefore, it is evident that the improvement in the knowledge of coastal current patterns will help to explain HAB phenomenons in Southern Chile fiords.

\section{Acknowledgements}

Miss Marcia Vera drew the map and mounted the pictures.

\section{Literature cited}

Arzul G. 1993. Red Tides. Training Courses given in Chile. Direction de l'Environnement et de l'aménagement Littoral. IFREMER, France. 104 pp.

Braarud T \& BR Heimdal. 1970. Brown water on the Norwegian coast in autumn 1966. Nytt Magasin for Botanik 17: 91 - 97.

Carreto JI, M Seguel, NG Montoya, A Clément \& MO Carignan. 2001. Pigment profile of the ichtyotoxic dinoflagellate Gymnodinium sp. from a massive bloom in southern Chile. Journal of Plankton Research 23 (10): 1171 - 1175.

Clément A. 1999. Floraciones nocivas de Gymnodinium sp. y sus efectos en la salmonicultura. Informe Técnico. Programa Monitoreo Fitoplancton INTESAL. 29 pp.

Clément A \& G Lembeye. 1993. Phytoplankton monitoring program in the fish farming region of South Chile. In: Smayda TJ \& Y Shimizu (eds), Toxic Phytoplankton Bloom in the Sea: 223 - 228. Elsevier Science Publishers B.V.

Clément A, M Seguel, G Arzul, L Guzmán \& C Alarcón. 2001. Widespread outbreak of a haemolytic, ichthyotoxic Gymnodinium sp. in Chile. In: Hallegraeff et al. (ed), Harmful Algal Bloom, UNESCO publisher (in press)

Cohen AL. 1974. Critical point drying. In: Hayat M A (ed), Principles and Techniques of Scanning Electron Microscopy 1: 44 - 112. Van Nostrand Reinhold, Cincinatti, Ohio, Toronto, London, Melbourne.

Cosper EM, VM Bricelj \& EJ Carpenter (eds). 1989. Novel Phytoplankton Blooms. Causes and Impacts of Recurrent Brown Tides and Others Unusual Blooms. Coastal and Estuarine Studies 35: 1- 799. Springer, Berlin.

Fraga S \& FJ Sánchez. 1985. Toxic and potencially toxic dinoflagellates found in Galician Rias (NW Spain). In: Anderson DM, AW White \& DG. Baden (eds), Toxic Dinoflagellates, Proceedings of Third International Conference on Toxic Dinoflagellates: 51 - 54. Elsevier, New York.

Gentien P, P Lazure \& B Raffin. 1998. Effect of meteorological conditions in spring on the extent of a Gymnodinium cf. nagasakiense bloom. In: Reguera B, J Blanco, M Fernández \& T Wyatt (eds), Harmful Algae: 200 - 207. Xunta de Galicia and Intergovernmental Oceanographic Comission of UNESCO, Spain.

Guzmán L, I Campodónico \& J Hermosilla. 1975. Estudios sobre un florecimiento tóxico causado por Gonyaulax catenella en Magallanes. I.- Distribución espacial y temporal de G. catenella. Anales Instituto de la Patagonia, Punta Arenas (Chile) 4: 173 - 183. 
Guzmán L, G Pizarro, C Alarcón, V Chacón, R Igor, E Barticevic, O Oyarzo, A Atalah \& J Foppiano. 1999. Difusión Programa Marea Roja en la Región de Magallanes y Antártica Chilena, Tercera Etapa. Primer Informe de Avance proyecto FNDR - XII Región / 20092815 - 0. Tomo I, 74 p. Instituto de Fomento Pesquero, Punta Arenas.

Hansen G, N Daugbjerg \& $\mathbf{P}$ Henriksen. 2000. Comparative study of Gymnodinium mikimotoi an Gymnodinium aureolum, comb. nov. (=Gyrodinium aureolum) based on morphology, pigment composition and molecular data Journal of Phycology 36: 394 - 410.

Hasle GR. 1978. 5.2.1. The inverted-microscope method. In: Sournia A. (ed.), Phytoplankton Manual, Monographs on Oceanographic Methodology 6. UNESCO. pp. 88 - 96.

Haywood A, L Mackenzie, I Garthwaite \& N Towers. 1996. Gymnodinium breve 'look alikes': three Gymnodinium isolates from New Zealand. In: Yasumoto T, Y Oshima \& Y Fukuyo (eds), Harmful and Toxic Algal Blooms: 227 - 230. Intergovernmental Oceanographic Commission of UNESCO.

Lembeye G. 1981. Segunda aparición del veneno paralítico de los mariscos (VPM) asociado a la presencia de Gonyaulax catenella, en Magalanes (Chile). Anales Instituto de la Patagonia, Punta Arenas (Chile) 12: 273 - 276.

Lembeye G, T Yasumoto, J Zhao, \& R Fernandez. 1993. DSP outbreaks in chilean fiords. In: Smayda TJ \& Y Shimizu (eds), Toxic Phytoplankton Blooms in the Sea: 525 - 529. Elsevier Science Publishers B.V.

MacKenzie L, A Haywood, J Adamson, P Truman, D Till, M Satake, \& $T$ Yasumoto. 1996. Gymnodimine contamination of shellfish in New Zealand. In: Yasumoto T, Y Oshima \& Y Fukuyo (eds), Harmful and Toxic Algal Blooms: 97 - 100. Intergovernmental Oceanographic Commission of UNESCO.

Mahoney J, P Olsen \& M Cohn. 1990. Blooms of a dinoflagellate Gyrodinium cf. aureolum in New Jersey coastal waters and their occurrence and effects. Journal of Coastal Research, 6 (1): 121 - 135.

Nielsen M, \& C Tønseth. 1991. Temperature and salinity effect on growth and chemical composition of Gyrodinium aureolum Hulburt in culture. Journal of Plankton Research. 13: 389 - 398.
Partensky F, \& A Sournia. 1986. Le dinoflagellé Gyrodiniun cf. aureolum dans le plancton de l'Atlantique nord: identification, écologie, toxicité. Cryptogamie Algologie, 7(4): 251 - 275.

Partensky F, P Gentien \& A Sournia. 1991. Gymnodinium cf. nagasakiense $=$ Gyrodinium cf. aureolum (Dinophycées). In: Sournia A, C Belin, B Berland, E Erard-Le Denn, P Gentien, D Grzebyk, C Marcaillou-Le Baut, P Lassus \& F Partensky (eds), Le Phytoplancton Nuisible des Côtes de France (de la biologie à la prévention): 63 - 82. IFREMER, France.

Partensky F, D Vaulot, A Coute \& A Sournia. 1988. Morphological and nuclear analysis of the bloom-forming dinoflagellates Gyrodinium cf. aureolum and Gymnodinium nagasakiense. Journal of Phycology 24: $408-415$.

Passow U. 1991. Vertical migration of Gonyaulax catenata and Mesodinium rubrum. Marine Biology 110: 455 - 463.

Roden CM, HJ Lennon, E Mooney, P Leaphy \& W Lart. 1981. Red tide, water stratification and phytoplankton species succesion around Sherkin Island south-West Ireland, in 1979. Journal of Sherkin Island 1: 50 - 68.

Tangen K. 1977. Blooms of Gyrodinium aureolum (Dinophyceae) in north European waters, accompanied by mortality in marine organisms. Sarsia 63: 123 - 133.

Taylor F, Y Fukuyo \& J Larsen, 1995. Taxonomy of harmful dinoflagellates. In: Hallegraeff GM, DM Anderson \& AD Cembella (eds), Manual of Harmful Marine Microalgae: 283 - 309. UNESCO, France.

Uribe J. 1992. Toxic shellfish kill twelve people in Chile. Red Tide Newsletter 5 (1): 3.

Uribe J, C Garcia, M Rivas \& N Lagos. 2001. First report of diarrhetic shellfish toxins in the Southern Magellanic fjords, Chile. Journal of Shellfish Research 20 (1) 69-74.

Villareal T A, A Mansfield \& EJ Buskey. 1997. Growth and chemical composition of the Texas brown tide forming pelagophyte Aureoumbra lagunensis. In: Reguera B, J Blanco, M Fernández \& T Wyatt (eds), Harmful Algae: 359 - 362. Xunta de Galicia and Intergovernmental Oceanographic Comission of UNESCO, Spain.

Widdows J, MN Moore, DM Lowe \& PN Salked. 1979. Some effects of a dinoflagellate bloom (Gyrodinium aureolum) on the mussels, Mytilus edulis. Journal of the Marine Biological Association, U.K. 59: 522 - 524. 